\title{
Study of Seger Family Strategy in Covid-19 Prevention Measures in Achieving Health Indicator Objectives of Sustainable Development Goals
}

\author{
Wijono ${ }^{1, *}$ Abdul Hafidz ${ }^{1}$ Mochamad Purnomo ${ }^{1}$ Dony Ardy Kusuma ${ }^{1}$ Dian Ayu Larasati ${ }^{2}$ \\ ${ }^{1}$ Sport Coaching Department, Universitas Negeri Surabaya,Surabaya,East Java, Indonesia \\ ${ }^{2}$ Geography Education Department, Universitas Negeri Surabaya,Surabaya,East Java, Indonesia \\ *Corresponding author. Email: wijono@unesa.ac.id
}

\begin{abstract}
Starting from the city of Wuhan in China, the new type of corona virus (SARS-CoV-2) has spread to various countries in the world and has caused the outbreak of COVID-19 everywhere. On March 11, 2020, WHO declared COVID-19 a pandemic. There are 12,438 positive cases of the Corona virus (COVID-19) in 34 provinces in Indonesia as of Friday $(6 / 5 / 2020)$. To increase endurance, of course, exercise is needed to maintain fitness in line with the SDGS target in 2030 to improve mental health and well-being, so this study aims to (1) Analyze Seger's family strategies in efforts to prevent Covid-19 in achieving sports development goals in achieving sustainable health in the city of Surabaya when viewed from the participation index, open space index, fitness index, and human resource index (2) Providing solutions to obstacles in implementing a fresh family. The research method used a survey method with data collection using observation, questionnaires and documentation. The data collected from the sample is used to measure the achievement of the selected index, to analyze the carrying capacity of the health sector. The target output of this study is to find out the immediate family strategy in the effort to prevent Covid-19 during the pandemic period, to develop strategies for achieving SDGs which are realized by increasing participation and fresh family videos.
\end{abstract}

Keywords: Covid-19, immune, fresh family

\section{INTRODUCTION}

After the stipulation of the COVID-19 pandemic, countries that have been infected must make various efforts to stop it. As reported by Healthline, the Director General of WHO, Tedros Ghebreyesus, stipulates four main things that must be done by a country, namely: Prepare and prepare, Detect, protect, and treat, Reduce spread and Innovate and learn. In line with this, the government has urged the public to undergo physical distancing and workers are asked to work from home or work from home only to prevent the spread of the virus more widely. These two appeals tend to make people less mobile. Studies show that lack of movement can reduce endurance. As a result, the risk of being infected with the corona virus is even higher.

The sports medicine specialist association recommends staying active while staying at home, and doing moderate-intensity physical exercise can boost your immunity.
The Provincial Government of East Java has a 'Seger' program (happy to move), this program aims to invite all levels of society to actively move anywhere and anytime. This program invites people to be healthy by always moving and continuing to exercise. Of course this has a very positive effect amid the Covid-19 pandemic, because exercise can increase endurance. This is also in line with the SDGS Kota Surabaya indicator, which is a healthy and prosperous life. Ensure a healthy life and can improve the welfare of all people of all ages. The SGDS indicator in the health sector requires support to ensure a healthy life with good sports development. The current sports development can be seen from the SDI index.

According to [1], SDI is a composite index that reflects the success of sports development based on four basic dimensions: (1) open space available for sports, (2) human resources or sports personnel involved in sports activities, ( 3 ) participation of community members to exercise regularly and (4) the degree of physical fitness achieved by the community. In doing sports, of course, it 
is also necessary to pay attention to the potential carrying capacity of the City of Surabaya in the health sector.

Based on the above background, the focus of this study is to analyze the family happy movement strategy in the effort to prevent Covid-19 to achieve health goals based on SDGS through sports development as seen from the participation index, open space index, fitness index, and human resource index. As well as a solution if there are obstacles in its implementation.

The objectives of this study are (1) to analyze the strategy of the Seger family in efforts to prevent Covid-19 in achieving sports development goals in achieving sustainable health in the city of Surabaya when viewed from the participation index, open space index, fitness index, and human resource index (2) Providing solutions to obstacles in implementing an immediate family.

The urgency of this research is to participate in the prevention of Covid 19 through sports, and from the results of the evaluation can formulate a strategy for achieving SDGS City of Surabaya in the health sector through the concept of a fresh family.

The objectives of this study are (1) to analyze the strategy of the Seger family in efforts to prevent Covid-19 in achieving sports development goals in achieving sustainable health in the city of Surabaya when viewed from the participation index, open space index, fitness index, and human resource index (2) Providing solutions to obstacles in implementing an immediate family.

The urgency of this research is to participate in the prevention of Covid 19 through sports, and from the results of the evaluation can formulate a strategy for achieving SDGS City of Surabaya in the health sector through the concept of a fresh family.

\section{METHOD}

This research uses survey research type. Incidental sampling method. Data analysis using descriptive quantitative. The purpose of this research is to find out sports development strategies to achieve health goals by means of community participation and the level of physical fitness of the citizens of the city of Surabaya.

This research is located in the city of Surabaya. This location was chosen based on the importance of measuring the participation index, open space index, fitness index, and human resource index.

Population is the overall value from the results of quantitative and quality calculations or measurements related to certain characteristics of all members of the collection which are complete and clear for their nature to be studied [2]. The population of this research is all residents of Surabaya City.

According to [2], the sample is a part of the whole as well as the characteristics of a population. Researchers use residential sampling techniques, namely how to take samples by chance, i.e. anyone who happens to meet the researcher can be used as a sample, if it is considered that the person who happens to be met is suitable as a data source [2]. Researchers determined as many as 400 respondents using incidental sampling technique which has provisions as respondents, namely residents of the city of Surabaya.

\subsection{Data Collection}

Data collection was carried out using the following techniques:

\subsubsection{Questionnaire}

The questionnaire is a data collection technique that is carried out by giving a set of written statements to the respondent to answer. The closed questionnaire used by the researcher as a research instrument, the method used is a closed questionnaire. The research questionnaire consisted of community participation in exercising during the COVID-19 pandemic and before the COVID-19 pandemic[3].

\subsubsection{Documentation}

[2] explains that documents are used in research because in many ways documents as data sources can be used to test, interpret, and even predict. This research uses open space documents and human resources.

\subsection{Data Analysis}

Data analysis is an analysis that is used to simplify data in an easy-to-read form

(a) The Participation Index is measured using the weekly frequency as the basis for the dimension of participation.

(b) The open space index is measured based on the ratio between the area of open space available and the population aged seven years and over.

(c) The fitness index is measured based on a test technique, namely using a multistage fitness test

(d) The human resource index is measured based on the ratio between the number of trainers and the population over the age of seven in an area.

(e) The sports development index is calculated using a formula. 


\section{RESULT AND DISCUSSION}

\subsection{Sport Activities Before the COVID-19 Pandemic}

Sport is an exercise which contains elements of recreation [4]. Physical activity such as exercise can boost the immune system. Physical activity occurs at various places and at various times. Before the pandemic, usually people can exercise normally and without being limited by distance, time, type of sport, sport venue and exercise motivation[5]. Sports activities before the pandemic are described as follows:

Exercise frequency in one week

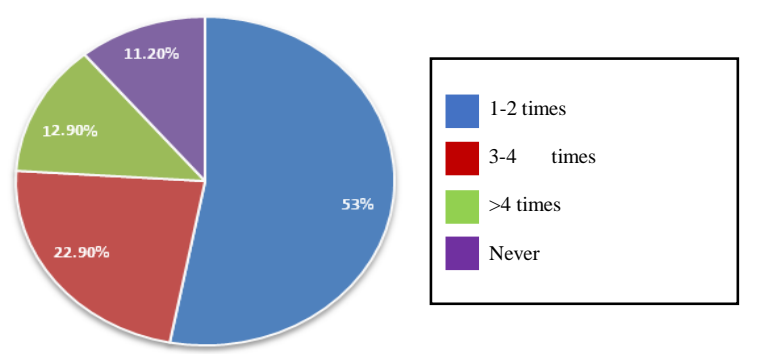

Figure 1. Exercise frequency in one week

Frequency is the length of time used by a person when exercising in one week. Respondents usually can exercise 1-2 times before the pandemic with a percentage of 53.1\% and respondents never exercise at $11.20 \%$. According to [6] the recommended frequency of exercise is 3-4 times a week

\subsubsection{Type of Sports}
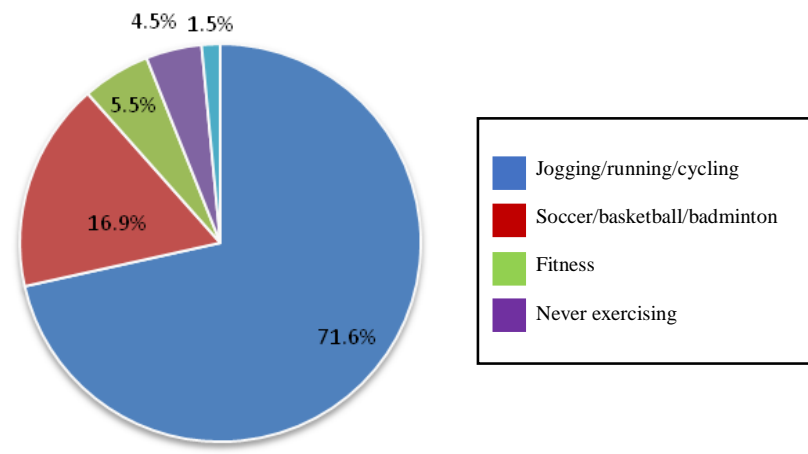

Figure 2. Type of sports

The usual exercise before the pandemic was jogging / running / cycling with a percentage of $71.6 \%$ and the lowest was never exercising at $1.50 \%$.

\subsubsection{A place to do sports}

The majority of respondents said they usually do sports outside of their homes and public facilities such as on their home yards, fields, stadiums and parks.

\subsubsection{Exercise time}
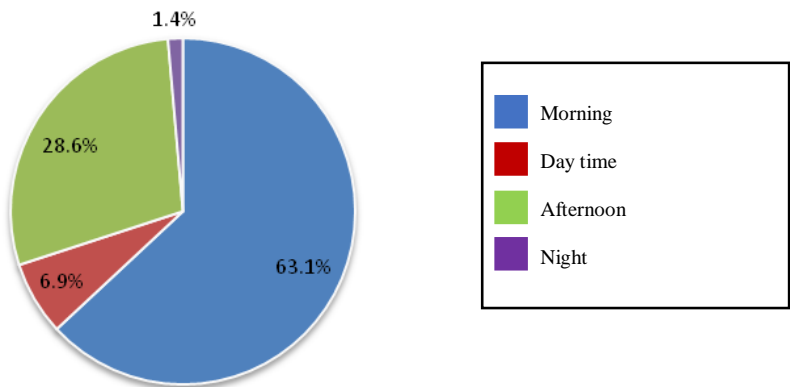

Figure 3. Exercise time

The usual exercise time for respondents before the pandemic was in the morning with a percentage of $63.1 \%$ and the lowest was at night with a percentage of $1.4 \%$.

\subsubsection{Exercise Duration}

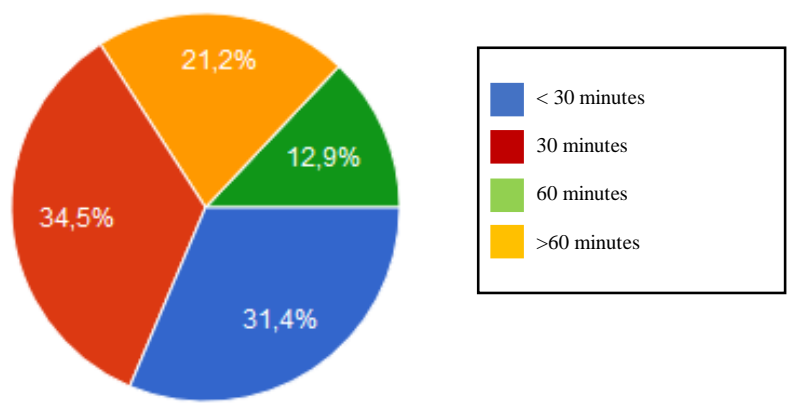

Figure 4. Exercise Duration

Duration is the time or length of time a person does exercise in one day. The duration of exercise that respondents usually do before the pandemic is 30 minutes with a percentage of $34.5 \%$ and the lowest is more than 60 minutes with a percentage of $12.9 \%$. 


\subsubsection{Sports motivation}
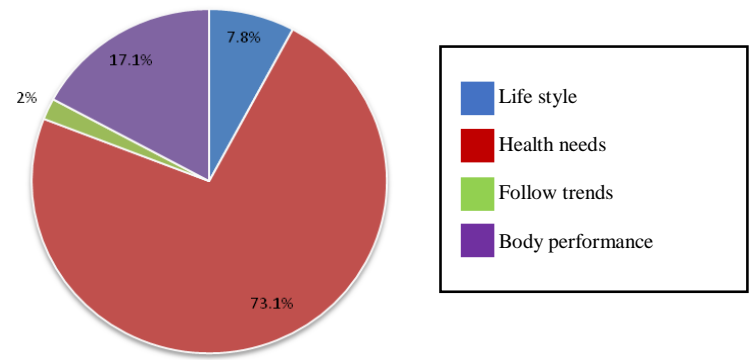

Figure 5. Sports Motivation

Sports motivation which was usually done by respondents before the pandemic was for health needs with a percentage of $73.1 \%$ and the lowest was to follow trends and social existence with a percentage of $2 \%$.

\subsection{Sport Activities During the COVID-19 Pandemic}

According to respondents, the COVID-19 pandemic can be prevented by exercising with a percentage of $32.5 \%$. Respondents answered that exercise could not be prevented with a percentage of $3.1 \%$. Respondents answered that they doubt and pessimism can be prevented by exercise with a percentage of $64.4 \%$.

According to respondents, it is very important to maintain health during the COVID-19 pandemic with a percentage of $87.3 \%$ and respondents who answered important were $12.7 \%$.

\subsubsection{How to stay in shape}

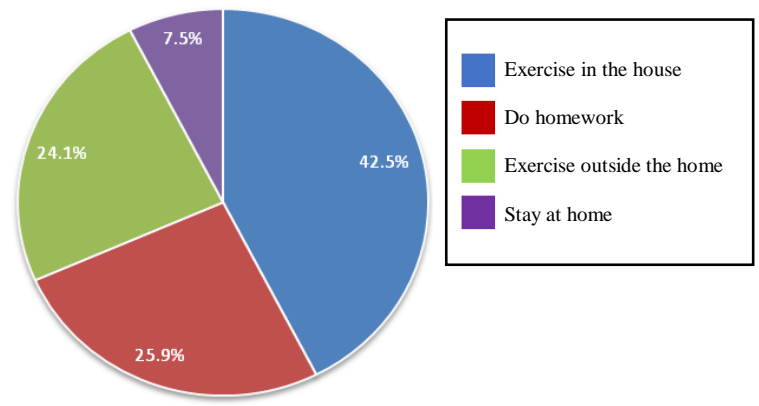

Figure 6 How to stay in shape

Fitness is a combination of activities and sports carried out at a sports venue, home or other place. Which was done to keep the body in shape during the COVID-19 pandemic by exercising at home with the highest percentage of $42.5 \%$. Staying at home is the lowest percentage at $7.5 \%$. Respondents believe that by exercising, the body becomes fit. However, during a pandemic like this, respondents think that their space is limited.

\subsubsection{Exercise frequency in one week}

Frequency is the length of time a person is exercising in one week during a pandemic. Respondents' exercise frequency at the time of the pandemic was almost never sports. This can be caused by various factors, namely laziness to exercise, it is better to do homework and work at home. Unlike the time before the pandemic, respondents did exercise 1-2 times a week.

\subsubsection{Type of Sports}

During a pandemic, people tend not to exercise. Respondents also still think that sports that can be done are outside the home by breathing fresh air so that it makes the body fresher. Even though exercising during a pandemic can increase immunity. Unlike before the pandemic, respondents were more dominant in doing sports outside the home such as swimming, playing football, fitness and jogging.

\subsubsection{A place to do sports}

The majority of respondents at the time of the pandemic wanted to do sports but they could do it at home. Because respondents still do not dare to exercise outside the home. Unlike before the pandemic, respondents can exercise freely in parks, fields, stadiums and fitness centers.

\subsection{Sport Facility Assessment}

\subsubsection{Sports field conditions}

The majority of respondents' satisfaction with the field sports facilities provided by the government is quite satisfied with a percentage of $47.8 \%$. Satisfied with the condition of the sports field by $13.5 \%$. Not satisfied with the condition of the sports field by $33.7 \%$. And very satisfied at $4.9 \%$.

\subsubsection{Maintenance of sports facilities}

Respondents' satisfaction with the maintenance of sports facilities carried out by the government, the majority answered that they were quite satisfied with a percentage of $49.6 \%$. Satisfied with the maintenance of sports facilities with a percentage of $3.5 \%$. Not satisfied with the percentage of $25.5 \%$. And very satisfied with the percentage of $21.4 \%$. 


\subsubsection{Complete sarpras and sports facilities}

The facilities and infrastructure provided by the government used for sports, according to respondents, are very complete with a percentage of $3.7 \%$. Respondents answered completely with a percentage of $15.1 \%$. Respondents answered quite complete with a percentage of $41.4 \%$ and incomplete with a percentage of $39.8 \%$.

The completeness of sports facilities provided by the government and used for sports, according to respondents, is very complete, amounting to $3.3 \%$. Respondents answered completely $17.1 \%$. Respondents answered quite completely with a percentage of $38 \%$. Respondents answered incompletely by $41.6 \%$.

\subsubsection{Access to sports facilities}

According to respondents, access to sports facilities is very good with a percentage of $9.2 \%$. Respondents answered well with a percentage of $49.4 \%$. Respondents answered enough with a percentage of $29.4 \%$ and less than $12 \%$.

\subsubsection{Distance to public sports facilities}

The average distance of public sports facilities from the house is $5-10 \mathrm{~km}$.

\subsection{Senang Gerak Family}

The concept of Jatim Seger is a new concept that is socialized by the Governor of East Java, the Governor of East Java invites all people to actively move in all fields, one of which is to exercise anywhere, anytime. It doesn't have to be in a specific sports facility, a fitness center, but any place that can free people to move can be used as a means for sports.

\subsubsection{The Seger Family Knowledge}

Most of the respondents' knowledge about fresh family said they did not know, with a percentage of $49.4 \%$. Respondents answered yes know by $37.6 \%$ and doubtful by $13 \%$.

\subsubsection{Seger Family Concept Agreement}

If the concept of fresh family is applied to residents of the city of Surabaya, the respondent agrees with a percentage of $68.2 \%$. Respondents answered disagree of $0.8 \%$.
Respondents answered doubtful by $19.6 \%$. And strongly agree with $11.4 \%$.

\subsubsection{Seger Family benefits}

Fresh families can provide benefits during a pandemic like now. Many respondents who know the benefits of this fresh family amounted to $71.6 \%$. Respondents answered don't know about $4.3 \%$. Respondents answered doubtful by $24.1 \%$.

\subsubsection{Application of the concept of a fresh family}

The implementation of the fresh family in Surabaya was greeted enthusiastically with the highest percentage, yes, you want to apply the concept of a fresh family of $91.8 \%$ and the rest do not want to apply it.

\subsection{Discussion}

COVID-19 is considered an obstacle to the achievement of SDGS in the health sector [7]. This epidemic threatens various agenda achievements for sustainable development that have been initiated for two decades. Anticipation measures against a pandemic have been taken, namely ensuring a healthy and prosperous life which targets the health sector and also needs improvement in terms of access, services and medical devices[8]

A study in the United States revealed the relationship between exercise and mental health conditions[9]. Those who exercise several times a week have better mental health than those who do not exercise [10]. Sport is an exercise which contains elements of recreation [11]. Physical activity such as exercise can boost the immune system. Physical activity occurs at various places and at various times. Before the pandemic, usually people can exercise normally and without being limited by distance, time, type of sport, sport venue and exercise motivation.

According to respondents, the COVID-19 pandemic can be prevented by exercising with a percentage of $32.5 \%$. Respondents answered that exercise could not be prevented with a percentage of $3.1 \%$. Respondents answered that they doubt and pessimism can be prevented by exercise with a percentage of $64.4 \%$. Based on the results of the study, respondents did sports activities before the pandemic such as swimming, fitness in the gym, soccer etc. However, after the COVID-19 pandemic, people tend to be lazy to exercise. Launching The Jakarta Post, a large study has proven that moderate to moderate exercise that is done about three times a week can reduce the risk of death during the Hong Kong flu outbreak in 1998. This can show that moderate exercise is also able to reduce the infection of COVID-19[12] 
East Java Seger is a happy motion concept that aims to move the wheels of East Java's life. Happy to move, one of which has been done by inviting all participants to do gymnastics together. This concept is in line with the health objectives of SDGS, namely ensuring the welfare and health of the community. Glad this motion can be done anytime and anywhere. It doesn't have to be in a specific sports facility, a fitness center, but any place that can free people to move can be used as a means for sports[13].

At the time of the current pandemic, the East Java concept could be applied immediately to maintain health. On the other hand, most of the respondents' knowledge about fresh family said they did not know with a percentage of $49.4 \%$.[14] Therefore, it is necessary to introduce the concept of fresh family to the community so that they can exercise anywhere. With a good frequency of exercise 3-4 weeks with a duration of 30 minutes is easy to achieve if there are correct exercise guidelines[15].

The city of Surabaya has adequate sports facilities, the location and price are also very affordable, some are even free. The location is very strategic, in the middle of the city of Surabaya[16]. Of course, this will make it easier for anyone to visit either to exercise or just to relax. Mostly, the gym with complete facilities is in city parks[17]. Sometimes the distance between respondents to reach city parks is still far. Public sports facilities near the respondents area are also inadequate. Based on the research results, respondents stated that the facilities and infrastructure provided by public sports facilities were incomplete.

The completeness of sports facilities can affect a person's interest in exercising. With sports facilities that are free and suitable for use, more people will exercise. So that it can achieve the goals of SDGS in the health sector.

\section{CONCLUSION}

The Seger family strategy in efforts to prevent Covid19 in achieving the goal of sports development in achieving sustainable health in the City of Surabaya when viewed from the participation index, open space index, fitness index and human resource index. Public participation during a pandemic is decreasing and they tend not to exercise. The solution to the obstacles in implementing an immediate family is by making videos and manuals.

With the concept of a fresh family, it is hoped that it can make it easier to make videos of happy motion and exercise manuals at home to be a reference for exercising during a pandemic.

\section{ACKNOWLEDGMENT}

Thank you for the assistance from PNPB Unesa.

\section{REFERENCES}

[1] Y. Suleyman, "Instruments for measuring service quality in sport and physical activity services," Coll. Antropol, vol. 36, no. 2, pp. 689-696, 2012.

[2] Sugiyanto, Model-Model Pembelajaran Inovatif. Surakarta: UNS, 2012.

[3] Sampeno, Forum Olahraga IV. Jakarta: Kemenpora, 1990.

[4] J. et Al, "Sport participation and subjective well being:Instrumental variable results from German survey data," J. Phys. Act. Heal. Hum. Kinet. Inc, pp. 396-403, 2014.

[5] "No Title." www.covid19.go.id.

[6] D. et $\mathrm{Al}$, "Pendugaan tingkat kesegaran jasmani. Buletin Penelitian Kesehatan,” Jakarta, 2001.

[7] M. Toho, C. Ali, Sport development index. Jakarta: PT. Indeks, 2007.

[8] "Sistem Keolahragaan Nasional (SKN) Nomor 3 Tahun 2005," 2005.

[9] H. Barrie, "Sporting excellence, schools and sports development," Polit. crowded policy spaces. Eur. Phys. Educ. Rev., vol. 6, no. 2, pp. 171-193, 2016.

[10] M. Mutohir, Sport development index. (Konsep metodologi dan aplikasi). Alternatif baru mengukur kemajuan pembangunan bidang keolahragaan. Jakarta: PT. Index, 2007.

[11] K. Douglas., Hartmann., Christina., "Sport and development: An overview, critique, and reconstruction," J. Sport Soc. Issues, vol. 35, no. 3, pp. 284-305, 2011.

[12] "No

Title.” https://www.sdg2030indonesia.org/page/11-tujuantiga.

[13] “PP RI No 19 Tahun 2005," 2005. .

[14] S. Giriwijoyo, Manusia dan olahraga. Bandung: ITB, 2005.

[15] D. Giriwijoyo, S; Zafar, Ilmu Kesehatan Olahraga. Bandung: ITB, 2005.

[16] N. Kusmaedi, Pembelajaran Hidup Sehat Terpadu Berbasis Masyarakat. Bandung: FPOK-UPI, 2002.

[17] WHO, "Coronavirus," 2019. [Online]. Available: https://www.who.int/emergencies/diseases/novelcoronavirus-2019/situation. 